\title{
Pemanfaatan Teknologi Informasi dalam Peningkatan Mutu Pendidikan Islam di Madrasah
}

\author{
Muhammad Aji Nugroho \\ Mahasiswa Progam Doktor Islamic Studies Pascasarjana IAIN \\ Walisongo Semarang \\ Email: khoira2013@gmail.com
}

\begin{abstract}
Abstrak
Perkembangan masyarakat dunia telah memasuki masyarakat informasi yang merupakan kelanjutan dari masyarakat modern dengan ciri-cirinya yang bersifat rasional, berorientasi ke masa depan, terbuka, menghargai waktu, kreatif, mandiri, dan inovatif, atau biasa disebut dengan global village yaitu Perkawinan antara teknologi transmisi mutakhir dengan komputer melahirkan sebuah era baru yaitu era informasi, yang dapat dikatakan sebagai world of the year. Disebut masyarakat informasi ditandai dengan penguasaan teknologi informasi, mampu bersaing, serba ingin tahu, imajinatif, mampu mengubah tantangan menjadi peluang, dan menguasai berbagai metode dalam pemecahan masalah. Sebab, problem yang muncul dizaman globalisasi ini jauh lebih kompleks dan memerlukan respons yang lebih beragam dan akomodatif, dan dengan menggunakan perangkat teknologi Informasi tersebut untuk mencari, mengeksplorasi, menganalisis, dan saling tukar informasi secara efisien dan efektif, siswa akan dengan cepat mendapatkan ide dan pengalaman dari berbagai kalangan dan pendidikan atau pembelajaran akan lebih berkembang dan terbantu terhadap proses pembelajaran bagi setiap siswa.
\end{abstract}


The world society development has entered into information society as a continuation of modern society. The characteristics of the information society is rational, future-oriented, open-minded, appreciate the time, creative, independent, and innovative. The time of global village will be born is the fusion of sophisticated transmission technology with a computer that yield a new era of information age, as the world of the year. Community information society is characterized by the mastery of information and technology, is able to compete, inquisitive, imaginative, and able to turn challenges into opportunities, and master various methods in problems solving. These challenges require a response that is more diverse and accommodating. Information and technology are solution and response that serves to find, explore, analyze, and exchange information efficiently and effectively. Thus, students will quickly get the ideas and experiences of the various circles, so that learning will be more developed and assisted with the process of study by student.

Kata Kunci: Teknologi Informasi, Pendidikan Islam, Pembelajaran.

\section{Pendahuluan}

Globalisasi telah memicu kecenderungan pergeseran dalam dunia pendidikan dari pendidikan tatap muka yang konvensional ke arah pendidikan yang lebih terbuka, bersifat rasional, berorientasi ke masa depan, terbuka, menghargai waktu, kreatif, mandiri, dan inovatif (Noer, 1987: 24). Era dimana akan lahir global village yang dikatakan sebagai world of the year, yaitu era tekhnologi informasi (Owens, Shaw, 1980:16). Seperti proyek Flexible Learning di Perancis tentang. "Pendidikan tanpa sekolah atau Deschooling Socieiy", yang secara ekstrimnya guru tidak lagi diperlukan. Bishop tahun 1989, meramalkan bahwa pendidikan masa mendatang akan bersifat flexible, terbuka, dan dapat diakses oleh siapapun juga yang memerlukan tanpa pandang faktor 
jenis, usia, maupun pengalaman pendidikan sebelumnya. Teknologi informasi pada masa globalisasi berkembang dengan cepat menurut deret ukur, yang memudahkan kehidupan manusia tanpa harus kehilangan kehumanisannya. Pendidikan merupakan kegiatan informasi, dan dapat disebarluaskan kepada generasi penerus suatu bangsa melalui tekhnologi informasi, mampu mengubah tantangan menjadi peluang, dan menguasai berbagai metode dalam pemecahan masalah (Rahmat, 1989: 46).

Mason R. pada tahun 1994, berpendapat bahwa pendidikan mendatang akan lebih ditentukan oleh jaringan informasi yang memungkinkan berinteraksi dan kolaborasi, bukannya dengan gedung sekolah. Tony Bates pada tahun 1995, menyatakan bahwa teknologi dapat meningkatkan kualitas dan jangkauan bila digunakan secara bijak untuk pendidikan dan latihan, dan mempunyai arti yang sangat penting bagi kesejahteraan ekonomi. Sementara Alisjahbana I. pada tahun 1966, mengemukakan bahwa pendekatan pendidikan dan pelatihan nantinya akan bersifat Just on Time. Teknik pengajaran baru akan bersifat dua arah, kolaboratif, dan inter-disipliner, yang memungkinkan peserta didik aktif dalam segala bentuk aktivitas pembelajaran dalam sekolah maupun diluar sekolah, dan dengan perkembangan tersebut tuntutan untuk mengembangkan pengetahuan semakin menjadi sebuah keharusan. (http://e-pendidikan.com). Sebab, problem yang muncul dizaman globalisasi ini jauh lebih kompleks dan memerlukan respons yang lebih beragam dan akomodatif. (Azra,1999: 11).

Pengaruh globalisasi pendidikan di masa mendatang akan lebih bersifat terbuka dan dua arah, beragam, multidisipliner, serta terkait pada 
produktivitas kerja dan kompetitif. dalam kehidupan dimasa mendatang, sektor teknologi informasi dan telekomunikasi merupakan sektor yang paling dominan, dan yang menguasai teknologi maka akan menjadi pemimpin dalam dunianya. Dengan demikian tanggung jawab sekolah yang besar dalam memasuki era globalisasi adalah mempersiapkan siswa-siswi untuk menghadapi tantangan-tantangan yang sangat cepat perubahannya. Salah satu dari tantangan yang dihadapi oleh para siswa adalah menjadi pekerja yang bermutu, mampu berbahasa asing, kemahiran komputer dan internet, dan menggunakan program-program seperti microsoft merupakan tiga kriteria utama sebagai syarat untuk memasuki lapangan kerja di Indonesia dan di seluruh dunia. Masuknya materi teknologi informasi dalam kurikulum pendidikan Islam, mempunyai posisi yang sangat penting sebagai salah satu media pembelajaran dalam mengoperasional informasi tersebut baik itu dalam mencari atau mendapatkan informasi, sehingga siswa akan cepat mendapatkan ide dan pengalaman dari berbagai kalangan, akan mengembangkan sikap inisiatif dan kemampuan belajar mandiri, dapat memutuskan dan mempertimbangkan penggunaan teknologi informasi secara tepat dan optimal, termasuk implikasinya dimasa datang.

\section{Metodologi}

Jenis penelitian ini adalah penelitian kualitatif yang menitik beratkan pada penelitian kepustakaan (library research) dengan mengkaji pemanfaatan teknologi informasi dalam peningkatan mutu pendidikan Islam di madrasah, melalui teks al-Qur'an atau hadis yang menjadi 
rujukan dalam pendidikan Islam, buku-buku, dan naskah yang bersumber dari khazanah kepustakaan yang relevan dengan permasalahan yang diangkat dalam penelitian ini (Efendy, 1989: 192). Sumber data yang digunakan buku atau kitab yang dijadikan pegangan utama berupa kajian pemanfaatan teknologi informasi dalam peningkatan mutu pendidikan Islam di madrasah, dan buku atau artikel yang masih dianggap relevan dengan kajian penelitian (Arikunto, 1993 :131). Metode analisis yang digunakan adalah analisis diskriptif, untuk menentukan hubungan antar kategori dengan yang lain, serta menginterpretasikan sesuai dengan peta penelitian yang dibimbing oleh masalah dan tujuan penelitian. Proses analisis data ini dilakukan untuk mewujudkan kontruksi teoritis sesuai dengan masalah penelitian (Surakhmand, 1980: 93).

\section{Pembahasan}

\section{Pengertian Teknologi Informasi}

Teknologi Informasi adalah suatu teknologi yang digunakan untuk mengolah data, termasuk memproses, mendapatkan, menyusun, menyimpan, memanipulasi data dalam berbagai cara untuk menghasilkan informasi yang berkualitas, yaitu informasi yang relevan, akurat dan tepat waktu, yang digunakan untuk keperluan pribadi, pendidikan, bisnis, dan pemerintahan dan merupakan informasi yang strategis untuk pengambilan keputusan. (http://e-majalah.com). Menurut Martin dalam Munir (2008: 9-10), memberikan makna bahwa teknologi informasi tidak terbatas pada teknologi komputer yang digunakan untuk memproses dan menyimpan informasi, melainkan juga mencakup teknologi komunikasi 
untuk mengirimkan informasi perbedaannya, teknologi informasi lebih mengarah pada sistem pengolahan informasi, sedangkan teknologi komunikasi berfungsi untuk pengiriman informasi (information delivery).

Adapun pengertian teknologi informasi dan komunikasi yang berimplikasi pada pemakaian komputer sebagai sarana ataupun media elektronik menurut para ahli teknologi informasi, adalah sebagai berikut: 1) Perangkat lunak (software) berisi pesan atau informasi pendidikan yang biasanya disajikan dengan mempergunakan peralatan (Sudirman, 2008: 19), 2) Saluran komunikasi yang digunakan untuk menyajikan pesan antara sumber (pemberi pesan) dengan penerima pesan (Latuheru, JD. 1993:11), 3) Segala sesuatu yang digunakan untuk menyalurkan pesan serta merangsang pikiran, perasaan, dan kemauan si belajar sehingga dapat mendorong terjadinya proses belajar yang disengaja, bertujuan dan terkendali (Miarso, 2004:458). 5) Teknologi Informasi adalah sebagai media yaitu, suatu perangkat yang dapat menyalurkan informasi dari sumber ke penerima informasi (Yamin, dkk, 2008:148).

Berdasarkan pendapat di atas, dapat disimpulkan bahwa teknologi informasi adalah sebuah media, bahan, atau alat maupun metode dan teknik yang digunakan dengan maksud agar interaksi informasi komunikasi dapat berlangsung secara efektif sesuai dengan tujuan yang diharapkan. yang digunakan untuk mengolah data, termasuk memproses, mendapatkan, menyusun, menyimpan, memanipulasi data dalam berbagai cara untuk menghasilkan informasi yang berkualitas. Hal inilah yang menjadi catatan penting pengembangan pendidikan Islam dengan teknologi informasi diyakini sangat membantu, pertumbuhan 
siswa dalam mengembangkan pemahamannya terhadap pelajaran atau materi yang dipelajari dari tenaga pendidik atau guru maupun buku ajar yang diterimanya, hal ini terjadi karena kontribusi dari pada teknologi informasi.

\section{Teknologi Informasi sebagai Media Pembelajaran Multimedia}

Teknologi informasi sebagai media pembelajaran multimedia, mempermudah siswa untuk dapat mengakses dan menerima berbagai informasi pembelajaran yang diperlukan, sehingga batasan geografis bukan menjadi masalah lagi. Pembelajaran dapat dilakukan dengan lebih mudah, karena siswa tidak perlu berjalan jauh menempuh ruang dan waktu untuk menemui seorang pakar dalam mendiskusikan sebuah masalah, karena dapat dilakukan dari rumah dengan saling tukar menukar data melalui Internet, via email (mengirimkan email), ataupun dengan menggunakan mekanisme file sharring dan mailing list. Sebagaimana Sharing information yang sangat dibutuhkan dalam bidang penelitian agar penelitian tidak berulang (reinvent the wheel). Hasil-hasil penelitian di perguruan tinggi dan lembaga penelitian dapat diakses bersama-sama sehingga mempercepat proses pengembangan ilmu dan teknologi misalnya, virtual university sebuah aplikasi internet yang memiliki karakteristik scalable, yaitu dapat menyediakan pendidikan yang diakses oleh orang banyak. Karena virtual university dapat diakses oleh siapa saja, darimana saja, dan dimana saja. (http://www.ibuteledukasi.com).

Ada beberapa manfaat Teknologi Informasi Sebagai Media Pembelajaran dalam bidang pendidikan, yaitu : 1) memperluas akses ke 
perpustakaan; 2) memperluas akses ke pakar; 3) melaksanakan perkuliahan secara online; 4) layanan informasi akademik suatu institusi pendidikan; 5) fasilitas sebagai pencari data; 6) menjadikan internet sebagai fasilitas diskusi; 7) menyediakan fasilitas direktori alumni dan sekolah; 8) menyediakan fasilitas kerjasama (http://ww.ecommerse.gov).

\section{Teknologi Informasi dan Globalisasi Informasi}

Collin Cherry dalam (Ibrahim, 1994: 74) mengungkapkan perkembangan teknologi informasi yang cepat dewasa ini dengan istilah exsplosion, hal ini karena, Pertama, secara potensial teknologi dapat menjangkau seluruh permukaan bumi hanya dalam tempo sekejap.

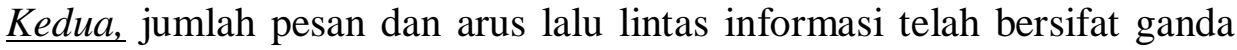
secara geometrik. Ketiga, Kompleksitas teknologinya sendiri semakin canggih (shopisticated), baik piranti lunaknya atau piranti kerasnya.

Globalisasi informasi, khususnya teknologi informasi memiliki potensi untuk ikut mengubah hampir seluruh sistem kehidupan masyarakat, politik, ekonomi, budaya dan sebagainya. Ciri-ciri globalisasi informasi adalah: 1) semakin tingginya peradaban yang ditopang oleh keberadaan ilmu pengetahuan dan tekhnologi, sehingga penguasaan dan pemanfaatan ilmu pengetahuan dan tekhnologi merupakan prasyarat untuk memenuhi kehidupan modern dari masyarakat global ini (Saefuddin, 1990: 157), 2) penyerbuan komunikasi dan informasi yang menembus batas-batas budaya. Hal ini dikarenakan istilah komunikasi berarti pemberitahuan, pemberian bagian, pertukaran dimana si pembicara mengharapkan pertimbangan atau jawaban dari 
pendengarnya dengan ikut mengambil bagian (Arifin, 1995:19), 3) tingginya laju transformasi social, 4) adanya perubahan gaya hidup (lifestyle), 5) semakin tajam perbedaan antara negara industri dengan negara berkembang. Dengan terjadinya dominasi informasi oleh negara berkembang terhadap negara yang terbelakang (Sophiaan, 1993:70).

\section{Pengaruh Teknologi Informasi dalam Pendidikan Islam}

Ilmu pengetahuan dan Tekhnologi merupakan dasar dan pondasi yang menjadi penyangga bangunan peradaban modern sekarang ini. Masa depan suatu bangsa akan banyak ditentukan oleh tingkat penguasaan bangsa itu terhadap Ilmu pengetahuan dan Teknologi. Suatu masyarakat atau bangsa tidak akan memiliki keunggulan dan kemampuan daya saing yang tinggi, bila ia tidak mengambil dan mengembangkan Ilmu pengetahuan dan Teknologi, hal ini bisa dimengerti apabila setiap bangsa sekarang ini, berlomba-lomba serta bersaing secara ketat dalam penguasaan dan pengembangan iptek. Islam datang kedalam dunia yang sudah sangat beradab, sebuah dunia dimana Babel, Firaun, Yunani, Romawi, Bizantium, Achaemenian dan Sasanian yang berprestasi dibidang matematika, asronomi, kedokteran dan teknik sudah berjalan dan sangat besar.

Islam merespon sangat cepat untuk memahami nilai pembelajaran ini, dengan pijakan bahwa Allah akan meningggikan derajat orang-orang yang berilmu sebagaimana tertuang dalam QS. AlMujadillah 58:11. Ayat ini memberi peluang kepada Ummat Islam untuk senantiasa mengembangkan diri dengan ilmu pengetahuan dan yang 
bermanfaat bagi kehidupannya melalui media apapun, seperti teknologi informasi, oleh karena itu menuntut ilmu wajib bagi setiap muslim. Hal ini dikarenakan dasar dari peradaban modern adalah ilmu pengetahuan dan teknologi, pengembangannya memberikan berkah dan anugrah yang luar biasa bagi kehidupan umat manusia. Terlebih lagi perkembangan teknologi informasi telah memberikan pengaruh terhadap dunia pendidikan khususnya dalam proses pembelajaran. Menurut Rosenberg, dengan berkembangnya teknologi informasi ada lima pergeseran dalam proses pembelajaran yaitu: 1) dari pelatihan ke penampilan; 2) dari ruang kelas ke di mana dan kapan saja; 3) dari kertas ke "on line" atau saluran; 4) fasilitas fisik ke fasilitas jaringan kerja; 5) dari waktu siklus ke waktu nyata, komunikasi sebagai media pendidikan dilakukan dengan media komunikasi seperti telepon, komputer, internet, e-mail (Muhammad Surya, 2006).

Interaksi antara guru dan siswa tidak hanya dilakukan melalui hubungan tatap muka tetapi juga dilakukan dengan menggunakan mediamedia tersebut. Guru dapat memberikan layanan tanpa harus berhadapan langsung dengan siswa, dan siswa dapat memperoleh informasi dalam lingkup yang luas dari berbagai sumber melalui cyber space atau ruang maya dengan menggunakan komputer atau internet, atau dengan istilah lain cyber teaching atau pengajaran maya, yaitu proses pengajaran yang dilakukan dengan menggunakan internet. Istilah lain yang makin poluper saat ini ialah e-learning yaitu satu model pembelajaran dengan menggunakan media teknologi komunikasi dan informasi khususnya internet. (http://www.elearning.gunadarma.ac.id). 
Menurut Rosenberg dalam Surya (2016), e-learning merupakan satu penggunaan teknologi internet dalam penyampaian pembelajaran dalam jangkauan luas yang belandaskan tiga kriteria yaitu: (1) e-learning merupakan jaringan dengan kemampuan untuk memperbaharui, menyimpan, mendistribusi dan membagi materi ajar atau informasi, (2) pengiriman sampai ke pengguna terakhir melalui komputer dengan menggunakan teknologi internet yang standar, (3) memfokuskan pada pandangan yang paling luas tentang pembelajaran di balik paradigma pembelajaran tradisional. Saat ini e-learning telah berkembang dalam berbagai model pembelajaran yang berbasis teknologi informasi dan komunikasi, seperti: Computer Based Training, Computer Based Instruction, Distance Learning, Distance Education, Cybernetic Learning Environment, Desktop Videoconferencing, Integrated Learning Syatem, Learner Cemterted Classroom, Teleconferencing, Web-Based Training dan sebagainya.

Satu bentuk produk Teknologi Informasi adalah internet yang berkembang pesat di penghujung abad ke-20 dan di ambang abad ke-21. Kehadirannya telah memberikan dampak yang cukup besar terhadap kehidupan umat manusia dalam berbagai aspek dan dimensi. Robin Paul Ajjelo dalam tulisannya yang berjudul "Rebooting: The Mind Starts at School". Dalam tulisan tersebut dikemukakan bahwa ruang kelas di era millenium yang akan datang akan jauh berbeda dengan ruang kelas seperti sekarang ini yaitu dalam bentuk seperti laboratorium komputer di mana tidak terdapat lagi format anak duduk di bangku dan guru berada di depan kelas. Ruang kelas di masa yang akan datang disebut sebagai 
"cyber classroom" atau "ruang kelas maya" sebagai tempat anak-anak melakukan aktivitas pembelajaran secara individual maupun kelompok dengan pola belajar yang disebut "interactive learning" atau pembelajaran interaktif melalui komputer dan internet, dan guru sebagai fasilitator. (Rahman, http://id.shvoong.com/internet-and-technologies).

Dalam tulisan itu, secara ilustratif disebutkan bahwa di masamasa mendatang isi tas anak sekolah bukan lagi buku-buku dan alat tulis, akan tetapi berupa: 1) komputer notebook dengan akses internet tanpa kabel, yang bermuatan materi-materi belajar yang berupa bahan bacaan, materi untuk dilihat atau didengar, dan dilengkapi dengan kamera digital serta perekam suara; 2) Jam tangan yang dilengkapi dengan data pribadi, uang elektronik, kode sekuriti untuk masuk rumah, kalkulator; 3) Videophone bentuk saku dengan perangkat lunak, akses internet, permainan, musik, dan TV; 4) alat-alat musik; 5) alat olah raga, dan; 6) bingkisan untuk makan siang. Hal itu menunjukkan bahwa di masa mendatang alat bantu belajar bernuansa internet, bila dimanage dengan baik dalam pendidikan Islam, maka teknologi informasi banyak menunjang proses pembelajaran secara lebih efektif dan produktif, dan meringankan dalam proses pembelajaran.

\section{Wilayah Pengembangan Ilmu Pengetahuan Islam dan Teknologi Informasi}

Islam adalah agama akal dan hati nurani, maka Ilmu pengetahuan menyediakan suatu cara yang dengan alam semesta, dan segala sesuatu di dalamnya, dapat diteliti guna menyingkap kehebatan 
dalam ciptaan Allah, sehingga pengetahuan ini dapat disampaikan kepada segenap manusia (Arkoun, 1996:134). Dengan demikian, agama mendorong ilmu pengetahuan, menjadikannya sebagai alat untuk mempelajari seluk-beluk ciptaan Tuhan. Islam membedakan dua wilayah bahasan pengembangan yang berkaitan dengan ilmu pengetahuan dan tekhnologi:

Pertama, berkaitan dengan urusan-urusan kemanusiaan yang mencakup politik, sosial, ekonomi, hukum, peribadahan, dan lainnya. Pengetahuan harus bersumber dari wahyu (kitab suci Allah). Wahyu menyuruh dan memerintahkan seluruh umat Islam untuk mengembalikan seluruh persoalan hanya kepada Allah (Al- Qur'an) (Sardar, 2000:25). Bagi Baiquni, berbicara tentang Islam dan ilmu pengetahuan berarti menunjukkan kesesuaian ayat-ayat al-Qur'an dengan temuan ilmu pengetahuan kontemporer. Ia, di antaranya, menunjukkan bahwa (pandangan mutakhir tentang alam semesta yang memuai) telah diisyaratkan dalam al-Qur'an.

Kedua, berkaitan dengan ilmu pengetahuan murni yang bersifat terbuka, yaitu yang berkaitan dengan ilmu murni (pure science), yang dihasilkan dari hasil olah pemikiran dan pemahaman manusia terhadap alam semesta. Ilmu pengetahuan ini tidak berkaitan dengan pandangan hidup seseorang, baik kapitalisme, Budhaisme, Kristianisme, maupun Islamisme. Dengan pembagian dan definisi tersebut, umat Islam pada masa pemerintahannya di masa silam mampu meraih kemajuan dalam semua bidang ilmu pengetahuan yang ada masa itu, bahkan mampu 
menjadi pionir dalam mengembangkan ilmu-ilmu pengetahuan yang baru (Sardar, 25-26).

Dengan demikian, maka Islampun telah mengatur dan menggariskan kepada ummatnya agar mereka menjadi ummat yang terbaik (dalam Ilmu Pengetahuan dan Tekhnologi) dan agar mereka tidak salah dan tersesat, dengan memberikan bingkai pengetahuan berdasarkan urutan kebenarannya ada empat sumber (Jalaluddin Rahmad 1998: 203), diantaranya adalah sebagai berikut :

\section{Al-Qur'an dan Sunnah}

Allah SWT telah memerintahkan hamba-Nya untuk menjadikan al-Qur'an dan Sunnah sebagai sumber pertama ilmu pengetahuan dan tekhnologi, ayat-ayat Al-Qur'an seakan mempunyai makna baru yang betul-betul sesuai dengan data dengan ilmu pengetahuan modern (Bucille, 1997: 251). Sebagaimana juga memberikan penjelasan keterkaitan antara penafsiran keagamaan dan kefilsafatan dengan mengutip beberapa ayat al-Quran yang mendorong manusia meneliti dan menggambarkan kajian penciptaan langit dan bumi dalam Qs. Al-'Araf 7: 185, Qs. Al-Imran 3: 191, Qs. Al-Ghaasyiyyah 88: 17-18. Dengan hal yang sama, al-Quran juga mendorong manusia melakukan perjalanan di bumi untuk mempelajari nasib peradaban sebelumnya. Ini membentuk kajian sejarah, arkeologi, perbandingan agama, sosiologi dan sebagainya secara utuh. Dalam Qs. Fushshilat 41: 53, secara kategoris, al-Quran menegaskan bahwa ayat-ayat Allah SWT di alam semesta dan di kedalaman batin manusia merupakan bagian yang berkaitan.

\section{Alam Semesta}


Allah SWT telah memerintahkan manusia untuk memikirkan alam semesta (QS. 3:190-192) dan mengambil berbagai hukum serta manfaat darinya, diantara ayat-ayat yang telah dibuktikan oleh pengetahuan modern seperti: Ayat asal mula alam semesta dari nebula Qs. 41: 11, urutan penciptaan Qs. 79: 28-30, bintang sumber panas yang tinggi Qs. 86: 3, teori ekspansi kosmos Qs. 51: 47, planet berada pada sistem tata surya terdekat (sama' ad-dunya) Qs. 37: 6, planet sebagai pemantul cahaya nur/kaukab dengan matahari sebagai sumber cahaya Qs. 71: 16, adanya gaya tarik antar planet Qs. 55: 7, revolusi bumi mengedari matahari Qs. 27: 88, matahari dan bulan memiliki waktu orbit yang berbeda-beda QS.55: 5, memiliki garis edar sendiri-sendiri yang tetap Qs. 36: 40, bumi ini bulat (kawwara-yukawwiru) dan berotasi Qs. 39: 5.

Ayat tentang akan sampainya manusia (astronot) ke ruang angkasa dengan ilmu pengetahuan Qs. 55: 33), tekanan udaranya rendah di angkasa Qs. 6: 125, jenis-jenis awan, proses penciptaan hujan es dan salju QS. 24: 43, awal kehidupan dari air Qs. 21:30, penciptaan manusia dari air mani Qs. 76: 2, nuthfah atau zygote yang melekat'alaqah segumpal daging atau embryo mudhghah dibungkus oleh tulang dalam misenhyme atau 'izhama tulang tersebut dibalut oleh otot dan daging Qs. 23: 14, Zygote dikokohkan tempatnya dalam rahim Qs. 22: 5, terjadinya air susu yang bermula dari makanan (farts) lalu diserap oleh darah lalu ke kelenjar air susu Qs 16: 66. Angin sebagai mediasi proses penyerbukan tumbuhan Qs. 15: 22, pada tumbuhan terdapat pasangan bunga jantan (etamine) dan bunga betina (ovules) yang menghasilkan perkawinan Qs. 13: 3. 
Diri Manusia dan Sejarahnya

Allah SWT memerintahkan agar manusia memperhatikan tentang proses penciptaannya, baik secara fisiologis Qs. 86: 5, maupun psikologis Qs. 91: 7-10, penciptaan manusia secara biologis Qs. 22: 5; 42: 49-50, banyak melukiskan watak manusia sebagai individu, seperti ketamakan Qs. 4: 36-37; 104: 1-3; 47: 38, kemunafikan Qs. 9: 7, senang tergesa-gesa Qs. 21: 37; 17: 11, kikir Qs. 17: 100; 70: 21, dan prilakunya sebagai anggota masyarakat, serta prilakunya manusia dalam masyarakat yang dilukiskan allah dalam al-Quran (Mutahhari, 1986: 61). Allah SWT memerintahkan manusia agar melihat kebenaran wahyu-Nya melalui lembar sejarah Qs. 12: 111. Seperti kaum Nuh, Hud, Shalih, Fir'aun, dan sebagainya, yang kesemuanya keberadaannya dibenarkan dalam sejarah hingga saat ini.

\section{Teknologi Informasi sebagai Peningkat Mutu Pendidikan}

Untuk dapat memanfaatkan Teknologi Informasi dalam memperbaiki mutu pendidikan Islam, ada tiga hal yang harus diwujudkan yaitu : 1) siswa dan guru harus memiliki akses kepada teknologi digital dan internet dalam kelas, sekolah, dan lembaga pendidikan guru; 2) harus tersedia materi yang berkualitas, bermakna, dan dukungan kultural bagi siswa dan guru, dan; 3) guru harus memiliki pengetahuan dan ketrampilan dalam menggunakan alat-alat dan sumber-sumber digital untuk membantu siswa agar mencapai standar akademik. Sejalan dengan pesatnya perkembangan Teknologi Informasi, maka telah terjadi 
pergeseran pandangan tentang pembelajaran baik di kelas maupun di luar kelas.

Dalam pandangan tradisional, proses pembelajaran dipandang sebagai: 1) sesuatu yang sulit dan berat, karena proses pembelajaran masih menekankan pada kemampuan tenaga pendidik dan stagnan pada SK dan KD yang diberikan; 2) upaya mengisi kekurangan siswa; 3) satu proses transfer dan penerimaan informasi; 4) proses individual atau soliter; 5) pembelajaran hanya menjabarkan materi pelajaran kepada satuan kecil dan terisolasi; 6) suatu proses linear. Sejalan dengan perkembangan teknologi informasi pandangan mengenai pembelajaran mengalami perubahan, yaitu sebagai; a) proses alami; b) proses sosial; c) proses aktif dan pasif; d) proses linear dan atau tidak linear; e) proses yang berlangsung integratif dan kontekstual; f) aktivitas yang berbasis pada model kekuatan, kecakapan, minat, dan kulktur siswa; g) aktivitas yang dinilai berdasarkan pemenuhan tugas, perolehan hasil, dan pemecahan masalah nyata baik individual maupun kelompok. Hal itu telah mengubah peran guru dan peran siswa dalam pembelajaran, adapun perubahan itu dapat dijelaskan sebagai berikut:

Peran guru telah berubah dari : a) penyampai pengetahuan, sumber utama informasi, ahli materi, dan sumber segala jawaban, menjadi sebagai fasilitator pembelajaran, pelatih, kolaborator, navigator pengetahuan, dan mitra belajar; b) dari mengendalikan dan mengarahkan semua aspek pembelajaran, menjadi lebih banyak memberikan lebih banyak alternatif dan tanggung jawab kepada setiap siswa dalam proses pembelajaran. Peran siswa telah berubah dari; a) penerima informasi 
yang pasif menjadi partisipan aktif; b) mengungkapkan pengetahuan menjadi menghasilkan pengetahuan; c) pembelajaran sebagai aktivitas individual (soliter) menjadi pembelajaran kolaboratif; d) lingkungan pembelajaran yang berpusat pada guru telah bergesar menjadi berpusat pada siswa. Secara rinci dapat digambarkan sebagai berikut:

\begin{tabular}{|c|c|c|}
\hline Lingkungan & Berpusat pada guru & Berpusat pada siswa \\
\hline Aktivitas kelas & $\begin{array}{llll}\text { Guru sebagai sentral dan } \\
\text { bersifat didaktis } & & \end{array}$ & $\begin{array}{l}\text { Siswa sebagai sentral dan } \\
\text { bersifat interaktif }\end{array}$ \\
\hline Peran guru & $\begin{array}{l}\text { Menyampaikan fakta-fakta, } \\
\text { guru sebagai akhli }\end{array}$ & $\begin{array}{l}\text { Kolaboratif, kadang-kadang } \\
\text { siswa sebagai akhli }\end{array}$ \\
\hline $\begin{array}{l}\text { Penekanan } \\
\text { pengajaran }\end{array}$ & Mengingat fakta-fakta & $\begin{array}{l}\text { Hubungan antara informasi } \\
\text { dan temuan }\end{array}$ \\
\hline Konsep pengetahuan & $\begin{array}{l}\text { Akumulasi fakta secara } \\
\text { kuantitas }\end{array}$ & Transformasi fakta-fakta \\
\hline $\begin{array}{l}\text { Penampilan } \\
\text { keberhasilan }\end{array}$ & Penilaian acuan norma & $\begin{array}{l}\text { Kuantitas pemahaman, } \\
\text { penilaian acuan patokan }\end{array}$ \\
\hline Penilaian & Soal-soal pilihan berganda & $\begin{array}{l}\text { Protofolio, pemecahan } \\
\text { masalah, dan penampilan }\end{array}$ \\
\hline $\begin{array}{l}\text { Penggunaan } \\
\text { teknologi }\end{array}$ & Latihan dan praktek & $\begin{array}{ll}\text { Komunikasi, } & \text { akses, } \\
\text { kolaborasi, ekspresi }\end{array}$ \\
\hline
\end{tabular}

Peran guru dalam pembelajaran diatas sebagai pemberi informasi harus bergeser menjadi manajer pembelajaran dengan sejumlah peran-peran tertentu, karena guru bukan satu-satunya sumber informasi melainkan hanya salah satu sumber informasi. Dalam bukunya yang berjudul "Reinventing Education", Louis V. Gerstmer, Jr. dkk (1995), 
(http://www.nusantara-news.com/) menyatakan bahwa di masa-masa mendatang peran-peran guru mengalami perluasan yaitu guru sebagai: pelatih (coaches), konselor, manajer pembelajaran, partisipan, pemimpin, pembelajar, dan pengarang. Guru merupakan kunci dalam peningkatan mutu pendidikan, yang berorientasi pada pencapaian kualitas murid, maka peningkatan kualitas pendidikan dalam sebuah sistem persekolahan menjadi tidak berarti jika tidak disertai oleh adanya guru yang professional (Surya, 2000: 1).

Dengan demikian dapat disimpulkan keprofesionalan seorang guru dapat diukur dari segi aktifitasnya dengan lingkup teknologi informasi yang merupakan sumber kreativitas dan pengembangan terhadap pendidikan yang sedang dilangsungkan. Oleh karena itu dalam mengembangkan guru yang professional, maka seorang guru tidak hanya dituntut untuk mempertebal kemampuan secara disipliner, tetapi lebih dari itu dituntut untuk mempunyai kualitas yang interdisipliner, harus ada pendekatan berbeda untuk disiplin spesialis yang berbeda (Ashrof, 1993:5).

\section{Teknologi Informasi sebagai Penunjang Kreativitas Belajar}

Dengan memperhatikan pengalaman beberapa Negara sebagaimana dikemukakan di atas, jelas sekali teknologi informasi mempunyai pengaruh yang cukup berarti terhadap proses dan hasil pembelajaran baik di kelas maupun di luar kelas. Teknologi Informasi telah memungkinkan terjadinya individualisasi, akselerasi, pengayaan, perluasan, efektivitas dan produktivitas pembelajaran yang pada 
gilirannya akan meningkatkan kualitas pendidikan sebagai infrastruktur pengembangan sumber daya manusia secara keseluruhan. Melalui penggunaan Teknologi Informasi setiap siswa akan terangsang untuk belajar maju berkelanjutan sesuai dengan potensi dan kecakapan yang dimilikinya. Pembelajaran dengan menggunakan Teknologi Informasi menuntut kreativitas dan kemandirian diri sehingga memungkinkan mengembangkan semua potensi yang dimilikinya (http://www.cianjurcybercity).

Dalam menghadapi tantangan kehidupan modern di abad ke-21 ini kreativitas dan kemandirian sangat diperlukan untuk mampu beradaptasi dengan berbagai tuntutan, dengan beberapa alasan antara lain: 1) memberikan peluang bagi individu untuk mengeksplor kemampuan dan kemauan dirinya dalam mengekpresikan segala aktivitas kehidupannya melalui daya imajinatif, 2) menemukan berbagai alternatif dalam pemecahan masalah, 3) memberikan kepuasan hidup dalam menjalani segala aktivitas yang dimilikinya, 4) meningkatkan kualitas dan taraf hidup manusia, menghasilkan rejeki karena kreativitasnya. Secara kognitif, kreativitas merupakan kemampuan berfikir yang memiliki kelancaran, keluwesan, keaslian, dan perincian. Secara afektif, kreativitas ditandai dengan motivasi yang kuat, rasa ingin tahu, tertarik dengan tugas majemuk, berani menghadapi resiko, tidak mudah putus asa, menghargai keindahan, memiliki rasa humor, selalu ingin mencari pengalaman baru, menghargai diri sendiri dan orang lain. 


\section{Teknologi Informasi sebagai Penunjang Kemandirian Belajar}

Kemandirian belajar sangat diperlukan dalam kehidupan yang penuh tantangan ini sebab kemandirian merupakan kunci utama bagi individu untuk mengarahkan dirinya ke arah tujuan dalam kehidupannya. Kemandirian didukung dengan kualitas pribadi yang ditandai dengan penguasaan kompetensi tertentu, konsistensi terhadap pendiriannya, kreatif dalam berfikir dan bertindak, mampu mengendalikan dirinya, dan memiliki komitmen yang kuat terhadap berbagai hal. Teknologi informasi memberikan informasi pada peserta didik yang tidak ada dalam buku ajar ataupun keterangan dari pengampu mata pelajaran tentunya, hal ini menjadikan siswa ini memperoleh banyak pengetahuan tentang materi ilmu pengetahuan baik yang berkesinambungan dengan yang dipelajari maupun dengan perluasan ilmu dan wacana yang lain.

Dengan memperhatikan ciri-ciri kreativitas dan kemandirian tersebut, maka dapat dikatakan bahwa Teknologi Informasi memberikan peluang untuk berkembangnya kreativitas dan kemandirian siswa (http://bptpdisdikjabar.net/). Pembelajaran dengan dukungan Teknologi Informasi memungkinkan dapat menghasilkan karya-karya baru yang orsinil, memiliki nilai yang tinggi, dan dapat dikembangkan lebih jauh untuk kepentingan yang lebih bermakna. Melalui Tekhnologi Informasi siswa akan memperoleh berbagai informasi dalam lingkup yang lebih luas dan mendalam sehingga meningkatkan wawasannya. Hal ini merupakan rangsangan yang kondusif bagi berkembangnya kemandirian anak dalam hal pengembangan kompetensi, kreativitas, kendali diri, 
konsistensi, dan komitmennya baik diri sendiri atau pihak lain (Poeradisastra, 1981:69).

\section{Kontribusi Teknologi Informasi terhadap Pendidikan Islam}

Pendidikan Islam adalah usaha sadar dan terencana dalam menyiapkan peserta didik untuk mengenal, memahami, menghayati, hingga mengimani ajaran agama Islam, dibarengi dengan tuntunan untuk menghormati penganut agama lain dalam hubungannya kerukunan antar umat beragama hingga terwujud persatuan dan kesatuan bangsa, dengan begitu manajemen dan pengelolaan pendidikan merupakan satu hal yang sangat penting dalam mengatasi kekrisisan yang disebabkan oleh permasalahan yang timbul dalam menjalankan pendidikan (Tilaar, 2004: xii). Berangkat dari pengertian diatas, maka perlu dimulai proses pembaharuan dan pengembangan pendidikan Islam dari lapangan, yaitu dari kelas, sekolah, serta dari pelaku pendidikan sendiri, seperi kepala sekolah, guru, dan siswa bahkan perlu juga melibatkan wali murid. Usaha pengembangan ini tidak hanya terkonsentrasi pada persoalan teoritis yang bersifat kognitif tapi mengubah pengetahuan agama yang kognitif menjadi "makna" dan "nilai" yang perlu diinternalisasikan dalam peserta didik lewat berbagai cara, media, dan forum (Abdullah, 1996:47).

Tafsir (2006: 96) berpendapat bahwa pendidikan Islam merupakan usaha sadar dan terencana dalam menyiapkan peserta didik untuk mengenal, memahami, menghayati, hingga mengimani ajaran agama Islam, dibarengi dengan tuntunan untuk menghormati penganut agama lain, sehingga tercipta kerukunan antar umat beragama hingga 
terwujud persatuan dan kesatuan bangsa, melalui pembinaan pribadi muslim yang berpadu pada perkembangan spiritual, jasmani, emosi, intelektual, dan sosial. Menurut Zulkarnain (2008: 19) pendidikan Islam bertujuan sebagai pengabdian diri manusia pada pencipta alam, dengan tidak melupakan kehidupan dunia, dengan keterbatasan peserta didik untuk mengembangkan pemahamannya, teknologi informasi menjadi solusi untuk mengakses pengetahuan sebagai bentuk pengembangan dari pemahamannya.

Sementara itu, seiring dengan laju pesatnya gerak pembangunan, organisasi publik maupun swasta semakin banyak yang mampu memanfaatkan teknologi informasi dan komunikasi yang dapat menunjang efektifitas, produktifitas, dan efisiensi mereka. Penerapan teknologi informasi dan komunikasi dalam pengembangan manajemen Pendidikan Islam agaknya dapat diidentikkan dengan penerapan teknologi informasi dan komunikasi di bidang pendidikan, yaitu dalam pembelajaran pendidikan Islam. Perkembangan ini ditandai dengan semakin pentingnya informasi dan pengelolaan data di dalam banyak aspek kehidupan manusia. Dengan tersedianya berbagai bentuk media komunikasi dan informasi, kini masyarakat memiliki pilihan lebih variatif bagi informasi yang ingin mereka dapatkan (Arifin, 1995:19). Hal ini merupakan aplikasi dari pemahaman ayat al-Qur'an QS. An-Nahl ayat 78. yang merupakan konsep awal dari pengembangan ilmu pengetahuan yang dimulai dari Informasi yang dikodifikasi dan dikembangkan melalui teknologi:

"Dan Allah mengeluarkan kamu dari perut ibumu dalam keadaan tidak mengetahui sesuatupun, dan dia memberi kamu 
pendengaran, penglihatan dan hati, agar kamu bersyukur." (QS. An-Nahl:78)

Ayat di atas dapat dipahami bahwa Allah telah menganugerahkan pada manusia indera yang dapat digunakan untuk mengembangkan ilmu pengetahuan, dari keadaan tidak tahu ketika lahir menjadi tahu, yang menjadi modal penting dalam mengembangkan kehidupannya, dan dalam pengembangannya pengetahuan tersebut diperlukan sebuah informasi yang telah didukung oleh teknologi, dalam pandangan Islam bahwa keberadaan agama Islam menjadi sumber motivasi pengembangan ilmu (Arifin, 1995:131). Dalam masalah ketelitian dalam menerima informasi, Islam menyarankan untuk melakukan check and recheck, sebagaimana Allah berfirman dalam Qs. al-Hujurat 49: 6

"Hai orang-orang yang beriman, jika datang kepadamu orang fasik membawa suatu berita, maka periksalah dengan teliti, agar kaтu tidak menimpakan suatu musibah kepada suatu kaum tanpa mengetahui keadaannya yang menyebabkan kamu menyesal atas perbuatanmu itu."

Sedangkan dalam masalah tanggung jawab dan etika kritik krontruktif dalam etika berkomunikasi dan menerima informasi, Allah telah menjelaskan dalam al-Qur'an pada surat Al-Isra' ayat 36, tentang tanggung jawab.

"Dan janganlah kamu mengikuti apa yang kamu tidak mempunyai pengetahuan tentangnya. Sesungguhnya pendengaran, penglihatan dan hati, semuanya itu akan diminta pertanggungan jawabnya." (QS. Al-Isra':36). 
Adapun kontribusi teknologi informasi pada era globalisasi dan informasi bagi perkembangan dan pembangunan komunikasi Islam di masa depan dapat diidentifikasi sebagai berikut: 1) sasaran efektif dalam penyebaran isu positif keislaman yang disebabkan era intercultural dan international communication, 2) tantangan konsep pendidikan Islam terhadap dominasi barat dalam imperialisme informasi menimbulkan sekularisme, kapitalisme, pragmatisme dan sebagainya (Maletzke, 1978: 409), 3) ekspose persoalan-persoalan yang mendatangkan efek yang berbanding terbalik dengan tujuan komunikasi dan informasi tersendiri, 4) menjaga impor teknologi komunikasi informasi dari dunia barat baik software ataupun hardware, sehingga mengadopsi nilai-nilai Islam, yang mana komunikasi dan informasi dunia barat dipandang sebagai komoditi, bukan moral atau etika (Maulana, 1993:10-11).

\section{Peluang Pengembangan Pendidikan Islam melalui Teknologi Informasi}

Informasi tidak akan pernah netral yang diciptakan dalam batas tertentu, peluang pengembangan pendidikan Islam melalui teknologi informasi dapat dijelaskan sebagai berikut. 1) teknologi informasi akan mempunyai arti bila memberikan sumbangan positif kepada masyarakat, hal ini terjadi bila ummat muslim menghasilkan informasi sendiri dengan perlengkapan yang relevan dan dapat memenuhi kebutuhan (Maulana, 1993: 32), 2) perubahan dari era industri menuju ke era informasi menyangkut orientasi masyarakat yang menjurus kemasalah ekonomi, akan mendatangkan kesempatan kerja bagi masyarakat muslim, 3) 
pengembangan komunikasi Islam pada masa mendatang dengan memperhatikan delapan konsep pokok islam yang berkaitan dengan penciptaan dan penyabaran informasi, yakni tauhid, 'ilm, hikmah, 'adl, ijma', syura', istislah, dan ummah (Maulana, 1993:32). 4) menjaga eksistensi tradisi Islam yang menjadikan komunikasi sebagai sarana utama dalam menyebarkan informas. Namun ingatan tidak dapat diandalkan sepenuhnya, sehingga catatan tertulis melalui bukupun mulai berlaku dalam penyebaran ilmu pengetahuan yang bisa diakses lewat internet untuk uptodate dan upgrade dari akar budaya masa lalu dalam kontek kekinian.

Ilmu pengetahuan tentang masyarakat dipengaruhi oleh empat jenis sistem informasi yang membentuk sifat dan karakternya, yaitu : 1) pandangan dunia yang merupakan sistem penginformasian yang terluas, mengaitkan kosmologi dengan etika, dan bias berorientasi teistik maupun non teistik; 2) pengetahuan tentang masyarakat (nasionalisme); 3) lembaga-lembaga sosial; 4) filsafat pribadi (Sardar, 1989:26). Sedangkan prinsip informasi bukan merupakan hak ekslusif dan bahan komoditi yang bersifat value-free, tetapi memiliki norma-norma, etika dan moral imperative yang bertujuan sebagi service membangun kualitas manusia secara paripurna. Jadi Islam meletakkan inspirasi tauhid sebagai parameter pengembangan teori komunikasi dan informasi dalam Islam (Amir, 1999:13).

Efektitas teknologi informasi menyangkut kontak sosial manusia dalam masyarakat. Ini berarti, kontak yang dilakukan dikaitkan dengan perilaku atau moralitas, melalui pesan yang disampaikan dengan pesan 
yang diterima. Hal ini dikarenakan informasi tidak bergantung pada jumlah besar kecilnya, tetapi bergantung pada sejauhmana informasi itu dimengerti, efektif dan efesien. Teknologi informasi dalam pendidikan islam, menyangkut nilai-nilai kebenaran, kesederhanaan, kebaikan, kejujuran, integritas, keadilan, kesahihan pesan dan sumber menjadi aspek penting dalam komunikasi Islam (Islamic Triangular Relationship), yang dibangun antara Allah, Manusia dan Masyarakat (Dzulkifli, 2001: 34).

Al-Qur'an menyediakan seperangkat aturan dalam prinsip dan tata cara pengaplikasian teknologi pendidikan yaitu fairness (kejujuran), accuracy (ketetapan atau ketelitian), tanggung jawab dan kritik konstruktif, lihat dalam Qs. Al Nur 24: 19 dan Qs. Al Nahl 16: 116. Kedua ayat diatas merupakan konsep Islam dalam pemanfaatan teknologi yang mempunyai peran pembentukan kepribadian pemakai teknologi, yang akan mengikuti keinginan dari pemakai, bila memiliki niat jahat akan berubah menjadi jahat, dan bila pemakai adalah orang yang baik maka teknologi informasi ini akan menjadi baik dan berguna bagi siapapun pemakai teknologi ini. Harapan pendidik pada madrasah agar kualitas anak didik dan suasana pembelajaran semakin berkembang, teratatasi sejalan dengan perkembangan telekomunikasi yang canggih dan murah.

\section{Kesimpulan}

Teknologi informasi memegang peranan sebagai teknologi kunci (enabler technology). Perkembangan Teknologi Informasi dapat 
meningkatkan kinerja dan memungkinkan berbagai kegiatan dapat dilaksanakan dengan cepat, tepat dan akurat, termasuk dalam dunia pendidikan. Dengan perkembangan Teknologi Informasi yang sangat pesat ini, mau tidak mau, siap ataupun tidak siap, akan semakin deras mengalirkan informasi dengan segala dampak positif dan negatifnya ke masyarakat Indonesia khususnya dalam bidang pendidikan Islam yang dirasa makin tertinggal. Perkembangan Teknologi Informasi memperlihatkan bermunculannya berbagai jenis kegiatan yang berbasis pada teknologi ini, termasuk dalam dunia pendidikan. Seperti penggunaan e-learning, e-library, e-education, e-mail, e-laboratory, dan lainnya. Para cendekiawan mengatakan bahwa pendidikan di masa depan dengan pengaruh globalisasi, akan bersifat terbuka dan dua arah, beragam, multidisipliner, dan kompetitif. Dengan demikian dimasa mendatang sektor teknologi informasi dan telekomunikasi merupakan sektor yang paling dominan. Siapa saja yang menguasai maka akan menjadi pemimpin dalam dunianya.

\section{Daftar Pustaka}

Abdullah, Amin. 1996. Studi Agama dan Historis. Jakarta: Pustaka Pelajar.

Al-Jawi, M. Siddiq. Peran Islam dalam Perkembangan Ilmu Pengetahuan dan Tekhnologi. www. Khilafah 1924.org.

Amir, Mafri. 1999. Etika Komunikasi Masa dalam Pandangan Islam. Jakarta: Logos Publication.

Arifin, Anwar. 1995. Ilmu Komunikasi Sebuah Pengantar Ringkas. Jakarta: Raja Grafindo Persada.

Arifin, Muhammad. 1995. Agama, Ilmu, dan Teknologi. Jakarta: Golden Terayon Press. 
Arkoun, Mohammed. 1996. Rethinking Islam, terj.Latiful Khuluq. Yogyakarta: Pustaka Pelajar.

Ashrof, Ali. 1993. Horizon Baru Pendidikan Islam, Terj. Sari Siregar. Yogyakarta: Pustaka Firdaus.

Azra, Azyumardi. 1999. Konteks Berteologi di Indonesia: Pengalaman Islam. Jakarta: Paramadina.

Bucaille, M. 1997. The Bible,The Qur'an and Science. Indianapolis: Nort American Trust Publication.

Departemen Agama RI. 1989. Alqur'an dan Terjemahannya. Semarang: Toha Putra.

Dzulkifli, Abdul Ghani. 2001. Islam, Komunikasi dan Tekhnologi Maklumat. Kuala Lumpur: Utusan Publications \& Distribution Sdn. Bhd.

Fischer, Dietrich and Jhon C. Merill. 1978. International and Intercultural Communication, New York: Communication Art Books, Hastings House Publiser.

Ibrahim, Marwah Daud. 1994. Tekhnologi Emansipasi dan Transendensi; Wacana Peradaban dengan Visi Isla., Bandung: Mizan.

Iqbal, Muhammad. 1997. The Reconstruction of Relegius Thought in Islam. Lahore: Sh.Mohammad Ashraf.

Latuheru, J.D. 1993. Media Pembelajaran dalam Proses Belajar Mengajar Kini. Ujung Pandang: Penerbit IKIP Ujung Pandang.

Maulana, Hamid. The New Global Order and Cultural Ecology, dalam Media Culture and Society, Vol. 15 No. 1 January 1993.

Miarso, Yusuf Hadi. 2004. Menyemai Benih Teknologi Pendidikan. Jakarta: Kencana Prenad Group.

Munir. 2008. Kurikulum Berbasis Teknologi Informasi dan Komunikasi. Bandung: Alfabeta.

Muslim. Teknologi Informasi dalam Pendidikan. http: //www.lights.com/hytelnet/sites1. Html.

Mutahhari, Murtadho. 1986. Masyarakat dan Sejarah: Kritik Islam atas Marxisme dan Teori Lainnya. Bandung: Mizan.

Noer, Deliar. 1987. Pembangunan di Indonesia. Jakarta: PT Mutiara.

Owens, Edger dan Robert Shaw. 1980. Pembangunan Ditinjau Kembali. Yogyakarta: Gajah Mada University Press.

Poeradisastra. 1981. Sumbangan Islam kepada Ilmu dan Kebudayaan Modern. Jakarta: Girimukti. 
Mudarrisa: Jurnal Kajian Pendidikan Islam, Vol. 6, No.1, Juni 2014: 30-60

Rahman. Pemanfaatan Teknologi Informasi dan Komunikasi sebagai Media Pembelajaran, http://id.shvoong.com/internet-andtechnologies/1948962-pemanfaatan-teknologi-informasi-dankomuni kasi/

Rahmat, Jalaluddin. Islam Menyongsong Peradaban Dunia Ketiga dalam Ulumul o=Qur'an, Vol. 2, 1989.

1998. Islam Alternatif Ceramah-Ceramah di Kampus. Bandung: Mizan Cet. Ke 9.

Saefuddin, AM. 1990. Desekularisasi Pemikiran; Landasan Islamisasi. Bandung: Mizan.

Sardar, Ziauddin. 1989. Tantangan Dunia Islam Abad 21, Terj. AE Priyono dan Ilyas Hasan. Bandung: Mizan.

. 2000. Merombak Pola Pikir Intelektual Muslim. Yogyakarta: Pustaka Pelajar.

Sudirman, Arief dkk. 2008. Media Pendidikan, Pengertian, Pengembangan dan Pemanfaatannya. Jakarta: Raja Grafindo Persada.

Surya, Muhammad. Teknologi Informasi dan Komunikasi Dalam Peningkatan Mutu Pembelajaran di Kelas; dalam Makalah Seminar "Pemanfaatan Teknologi Informasi dan Komunikasi untuk Pendidikan Jarak Jauh dalam Rangka Peningkatan Mutu Pembelajaran". Pustekkom; Depdiknas, tanggal 12 Desember 2006 di Jakarta.

. Aspirasi Peningkatan Kemampuan Professional dan Kesejahteraan Guru: dalam Jurnal Pendidikan dan Kebudayaan, No. 21, Tahun ke 5, Januari 2000.

Sophiaan, Ainur Rofiq. 1993. Tantangan Media Informasi Islam, Antara Profesionalisme dan Dominasi Zionis. Surabaya: Risalah Gusti.

Tafsir, Ahmad. 2006. Filsafat Pendidikan Islami. Bandung: PT. Remaja Rosdakarya.

Tilaar, H.A.R. 2004. Manajemen Pendidikan Nasional: Kajian Pendidikan Masa Depan. Bandung: PT Remaja Rosdakarya.

Yamin, Martinis dkk. 2008. Taktik Mengembangkan Kemampuan Individual Siswa. Jakarta: Gaung Persada Press Jakarta.

Zulkarnain. 2008. Transformasi Nilai-Nilai Pendidikan Islam; Manajemen Berorientasi Link and Match. Yogyakarta: Pustaka Pelajar. 
http://bptpdisdikjabar.net/content/read/fungsi_teknologi_informasi_dan_ komunikasi_dalam_pembelajaran.html.

http://elearning.gunadarma.ac.id/

http://e-majalah.com/art05-92.html.

http://e-pendidikan.com/,

http://idb2.wikispaces.com/file/view/ok2015.pdf.

http://www.al-shia.org/html/id/books/001/02.html.

http://www.cianjurcybercity.com/2009/01/11/pentingnya-teknologi-

informasi-dalam-pendidikan. html.

http://www.ecommerce.gov.

http:// www.ibuteledukasi.com.html.

http://www.kamadeva.com/menu-news-newsid-tiduniapendidikan.htm. 